Wilfrid Laurier University

Scholars Commons @ Laurier

$10-2013$

\title{
The Assimilated Asian American as American Action Hero: Anna May Wong, Keye Luke, and James Shigeta in the Classical Hollywood Detective Film
}

Philippa Gates

Wilfrid Laurier University, pgates@wlu.ca

Follow this and additional works at: https://scholars.wlu.ca/engl_faculty

Part of the English Language and Literature Commons, Film and Media Studies Commons, and the Race and Ethnicity Commons

\section{Recommended Citation}

Gates, P. (2013). "The Assimilated Asian American as American Action Hero: Anna May Wong, Keye Luke, and James Shigeta in the Classical Hollywood Detective Film." Canadian Journal of Film Studies 22(2), 19-40.

This Article is brought to you for free and open access by the English and Film Studies at Scholars Commons @ Laurier. It has been accepted for inclusion in English and Film Studies Faculty Publications by an authorized administrator of Scholars Commons @ Laurier. For more information, please contact scholarscommons@wlu.ca. 


\section{THE ASSIMILATED ASIAN AMERICAN AS AMERICAN ACTION HERO: ANNA MAY WONG, KEYE LUKE, AND JAMES SHIGETA IN THE CLASSICAL HOLLYWOOD DETECTIVE FILM}

\section{PHILIPPA GATES}

In Hollywood film, there is a distinction made between "Asian” as a racial and national category and "Asian American" as an ethnic one-the former often being criminalised for their cultural autonomy while the latter were lauded when they assimilated into mainstream, American culture. ${ }^{1}$ While Charlie Chan embodies the former, he is one of the rare examples of an Asian character at the center of a Classical Hollywood film who was presented as the hero, namely the protagonist with whom the mainstream (read: white) filmgoer was aligned. Chan appeared in forty-seven Hollywood films in the 1930s and 40s (as well as a handful of Spanish- and Chineselanguage remakes) and his popularity led other Hollywood studios to produce series featuring imitators Mr. Wong and Mr. Moto. There has been much debate amongst scholars as to whether the Asian detective represents a positive image of Asian masculinity: Chan is a hero, unlike the infamous villain Dr. Fu Manchu, and works to reinstate social order on the side of the law; however, he is simultaneously presented as a servant to Western interests and is played in “yellowface” by a white actor. Chan, Wong, and Moto are notable for being some of the few Asian detectives to feature in Hollywood film and, even more so, for being popular enough to sustain a series. Indeed, there has been only one Asian series detective in Hollywood film since the Classical-era, Detective Inspector Lee of the Rush Hour films (Brett Ratner 1998, 2001, and 2007) played by Hong Kong action star Jackie Chan. While much scholarship has addressed the prolific but problematic figure of Charlie Chan in terms of his embodiment of Asian subjectivity and Hollywood's racial politics, far less attention has been directed to the Asian American detectives played by Asian American actors. The aim of this paper is not to debate whether or not the Asian detective played in "yellowface” by white actors is a racist caricature as that has been explored thoroughly in Asian American studies scholarship. ${ }^{2}$ Instead, in this paper, I will explore the representation of the Asian American detective played by Asian American actors in 
the same era of Hollywood film that saw the popularity of Asian detectives Chan, Wong, and Moto.

The Paramount's Daughter of Shanghai (Robert Florey 1937) starring Anna May Wong and Philip Ahn and Monogram's Phantom of Chinatown (Phil Rosen 1940) starring Keye Luke and Lotus Long are notable for their casting of Asian Americans in the leading roles, thus foregrounding Asian American subjectivity as central in decades when it was all but absent from the American screen. As Hye Seung Chung argues, “In Daughter of Shanghai, Ahn and Wong dismantled Oriental stereotypes” ${ }^{3}$ and I would argue, in a similar way, so too do Luke and Long in Phantom of Chinatown. It would follow then that Sam Fuller's critically-praised and independently-produced The Crimson Kimono (1959) should provide a more radical message as it was made in a period when the power of both the Studio System and Production Code were waning and it features an interracial romance. As I will demonstrate, however, the message in Hollywood film from Charlie Chan to The Crimson Kimono was that “otherness” was most desirable when assimilated. While the character of the detective provided a space for the representation and exploration of Asian or Asian American subjectivity, the detective was required to sublimate his/her bicultural status in favour of his/her profession and its alignment to the interests of mainstream (white) America. More importantly, however, I will demonstrate that for Hollywood producers the "problem" of Asian/Americanness was less the race of the actor who portrayed the detective than the race of the character of the detective him/herself. While Classical Hollywood's Asian American detectives-like its Asian detectives-were considered most appealing and/or less threatening when assimilated, they-unlike Chan, Wong, and Motowere aligned with decidedly American ideals of heroism, including sexuality and action.

\section{Yellow Peril to Yellowface}

The stereotype of the Hollywood “Asian” was solidified in silent American films. As Sue Fawn Chung notes, “Chinese laundrymen, laborers, miners, houseboys, opium smokers, idolators, criminals, and tong men were portrayed as cruel, cunning, or diabolically ingenious."4 Doobo Shim explains, the Chinese were the "unassimilable other," portrayed as exotic and foreign and living in the segregated community of Chinatown. ${ }^{5}$ As Krystyn Moon argues, "Conceptions of their deviance and inferiority left little room for their acceptance into American society and culture.” ${ }^{6}$ As Asian American studies scholars have argued, Hollywood’s representation of the 
Chinese was likely a reaction to, and exploitation of, perceived socio-political concerns over the influx of Chinese immigrants (resulting in the Immigration Act of 1924 that denied Asian immigration into the U.S.). There was a virtual absence of Chinese characters on the screen and then the rise of the “Oriental villain,” including Sax Rohmer’s infamous Fu Manchu whom Eugene Franklin Wong describes as "the epitome of Chinese treachery and cunning."7 As Rohmer himself described his character in The Return of Dr. Fu Manchu (1916):

Imagine a person, tall, lean and feline, high-shouldered, with a brow like Shakespeare and a face like Satan, a close-shaven skull, and long, magnetic eyes of the true catgreen. Invest him with all the cruel cunning of an entire Eastern race, accumulated in one giant intellect, with all the resources of science past and present, and you have a mental picture of Dr. Fu-Manchu, the "Yellow Peril” incarnate in one man. ${ }^{8}$

Fu Manchu’s popularity saw many imitators in film, including The Mysterious Wu Chung Foo in a four-part serial in 1914, Wu Fang in three silent serials starring Pearl White as The Lightning Raider (1919), and Baron Huroki of the 1917 series Patria. While these villains propagated the fear that Asians would overrun America, 1925 saw a radical shift from the Asian as evil genius to a popular hero. "Yellow Peril" fears began to subside because of the halt of immigration that the Immigration Act of 1924 enacted, the visibility of a growing native-born Chinese-American population, and the Japanese being cast as the new Asian villain as a result of Japan's undeclared war on China throughout the 1930s. ${ }^{9} 1925$ also saw the Saturday Evening Post launch a series by Earl Derr Biggers featuring Charlie Chan, an acculturated Chinese detective of the Honolulu Police Department, who would prove to be "arguably the first nonwhite popular detective in literary history." ${ }^{10}$ Interestingly, Biggers was surprised by the popularity of Chan as he had been concerned about the response on the part of Americans to the benign portrait of a Chinese character. $^{11}$

Chan appeared in Hollywood films soon after his debut in fiction but only as a minor character played by Japanese actors in the silent films The House without a Key (Spencer Gordon Bennet 1925) and The Chinese Parrot (Paul Leni 1927), and Korean actor E. L. Park (with a British accent) in the early sound film Behind that Curtain (Irving Cummings 1929). ${ }^{12}$ Two years later he was recast as the lead investigator in Charlie Chan Carries On (Hamilton MacFadden 1931) but, this time, was played by Swedish-born Warner Oland. Oland played the Chinese detective in sixteen films until his death in $1938,{ }^{13}$ then Sidney Toler for twenty-two 
installments until his death in 1947, ${ }^{14}$ and then Roland Winters for the last six films. ${ }^{15}$ In an attempt to cash in on Chan's popularity with audiences, Twentieth Century Fox created the Mr. Moto series starring Peter Lorre, ${ }^{16}$ and Monogram, the Mr. Wong series starring Boris Karloff. ${ }^{17}$ All of these actors (Oland, Toler, Winters, Lorre, and Karloff) shared in common the fact that they were white and played their respective detectives in "yellowface"-with the assistance of make-up, facial hair, prosthetics like false teeth, and adhesive tape to alter the shape of their eyes. Chan was characterized as "Chinese" through his quiet and controlled manner, his halted English, and with his tendency to offer pearls of Confucian (although sometimes more like fortune cookie) wisdom during his investigations. He applied his aphorisms, which became known as "Chanisms” or “Chanograms,” to human nature and also criminal investigation: "Facts like photographic film,” he explains, "Must be exposed before developing.” ${ }^{18}$ As Oscar Rimoldi states, "He had erudition without arrogance, impeccable manners, perfectly tailored suits and a progeny of Asian Americans totally in tune with the American way of life.”19

More critically, Jun Xing suggests, "the Charlie Chan character became institutionalized as the nonthreatening Asian (read: a physical wimp, a sexual deviant, and a political yesman).” ${ }^{20}$ Indeed, while Chan's expertise as a detective may be the result of his "Chinese" understanding of human nature, his appeal to American audiences was the fact that he was a polite, soft-spoken, well-groomed, family man who had adopted middle-class, American values. Indeed, Chan is regarded as just as much a stereotype as the "Yellow Peril” villain Fu Manchu, although embodying opposing values: he was the "model minority"-a term referring to immigrants who had assimilated into mainstream culture. ${ }^{21}$ As Karla Rae Fuller argues, "The archetype [of the 'Oriental detective'] survives as a cinematic depiction that is simultaneously novel and yet deeply conventional. These movie characters served the cultural status quo while appearing to modify it." ${ }^{22}$ In other words, through the Asian detective, Hollywood could simultaneously proffer the on-screen representation and characterization of the "other” while simultaneously neutralizing any "threat" that that representation might incite through a variety of strategies of containment.

In reference to African Americans on screen, Ed Guerrero argues, "Hollywood has deployed a variety of narrative and visual 'strategies of containment' that subordinate the Black image and subtly reaffirm dominant society’s traditional racial order.” ${ }^{23}$ These strategies include having the black actor showcased in comic rather than dramatic roles, isolated from other blacks 
(lacking a black community), presented as "romantically sanitized" (asexual), placed in the assumed feminine position of object of the spectatorial gaze, denied the opportunity to perform heroic action, and share the centre of the narrative with a white star. These strategies are regarded as necessary by the mainstream film industry in order to negotiate the potentially problematic cross-racial identification of white viewer with black hero. Similarly, any potential cross-racial "threat" that Classical Hollywood's Asian detective might be feared to invite was contained through the denial of sexuality, an Asian community, and/or the ability to perform action. The model minority Asian detective, as embodied by Chan and Wong, was non-assertive, the opposite of what was traditionally considered masculine (read: American); in other words, they were feminized. As Lisa Lowe suggests, until 1943 Chinese American male immigrants occupied a "feminized position" in relation to the universalized national white male citizen: they tended to work in occupations associated with women (laundries, tailor shops, and restaurants) and were denied the opportunity to become American citizens. ${ }^{24}$ As David L. Eng explains, the idea of "Oriental" was established in Western culture as the antithesis of masculinity and a link between sexuality and racialization in regards to Asian Americans has led critics to identify Fu Manchu as a homosexual menace and Chan as "a closet queen." ${ }^{25}$ The dominant stereotype of Asian masculinity, however, is that of the asexual Asian male. ${ }^{26}$ So despite his brood of children (eleven at the beginning of the series and fourteen by the end), Chan was presented-like Moto and Wong - as asexual. Indeed none of them share romantic moments with women, not even Chan with his wife (she is rarely shown and in the later films not even mentioned). Importantly, this feminization and containment also sees the detective denied the opportunity to be men of action —and action, then as it is today, is a key determinant of American heroism. ${ }^{27}$ The Asian detective's impeccable manners and appearance, deferential behavior, intellectualism, and lack of sexuality, marked him as un-American. This does not, however, negate the fact that he was intended by film producers to be, and recognized by audiences as, a hero-just an exotic one.

Critics and scholars have questioned whether the jettisoning of an ethnic minority into a mainstream heroic role constitutes a positive representation. Gina and Andrew Macdonald suggest that these early Asian detectives represent "faux ethnicity" - a "stereotyped exploitation of the exotic rather than being serious explorations of the experience of the Other." ${ }^{28}$ On the one hand, it can be argued that the Asian detective is portrayed as a hero: he occupies the center of the narrative, his investigation drives the narrative forward, and he is the man that solves the 
mystery and brings the criminal to justice. On the other, his representation is "colorblind:” there is no consideration of the ethnicity of the character or exploration of the racism that he would encounter as a minority in mainstream society. Indeed, Hollywood was as guilty of being colorblind and conflating different cultures in the 1930s as it is today-for example, the controversy over the casting of Chinese actors in leading roles in Memoirs of a Geisha (Rob Marshall 2005). The original script for Charlie Chan at the Opera (H. Bruce Humberstone 1936) was not intended as a Chan picture: the "Revised Outline" of the film (called Murder in the Opera at that point) by Bess Meredyth (dated 23 Jan 1936) features an American detective called Craddock. The first two Monogram films starring Roland Winters as Chan-The Chinese Ring (William Beaudine 1947) and Docks of New Orleans (Derwin Abrahams 1948)—are remakes with little alteration of Mr. Wong in Chinatown (William Nigh 1939) and Mr. Wong, Detective (William Nigh 1938), respectively. Similarly, when Oland died suddenly in 1938, the next script in the Chan series (Charlie Chan at the Ringside) was reworked into Mr. Moto's Gamble (James Tinling 1938), retaining many “Chanisms” and Chan’s “Number One Son” (played by Keye Luke). Such interchangeability between American (Craddock) and Asian (Chan), or Chinese (Chan) and Japanese (Moto) suggests a lack of respect for the specificity of different racial subjectivities.

The lingering cultural conception of Charlie Chan more than eighty years since Oland first played him on the screen is that he was a racial stereotype. Indeed, a Charlie Chan film festival was planned for the Fox Movie Channel in the summer of 2003 then was almost cancelled after complaints were received from Asian American groups and civil rights organizations about the films as perpetrating racist stereotypes and casting white actors in Asian American roles. The festival was salvaged, as Andrew Wallenstein of the Hollywood Reporter explains, through the additions of wrap-around commentary segments that featured panel discussions on racial insensitivity in film. ${ }^{29}$ However, critics remained critical and, as Herman Wong argues, “The ultimate racial taunt is still Charlie himself, right there on the screen, played by whites in yellow-face, and with all those ludicrous mannerisms. No, Charlie Chan was never our role model. He remains an incredulous screen token.” ${ }^{30}$ Despite concerns of racism, some film historians have defended Chan as a positive representation because he appeared in an era devoid of Asian/American protagonists. Even Asian American actor Keye Luke, who played Chan’s “Number One Son” in ten films, described Chan as “a Chinese hero” for Chinese 
Americans. ${ }^{31}$ Ken Hanke attributes the practice of "yellowface" in Hollywood not to racism but the star system. ${ }^{32}$ Indeed, stardom, or star bankability, was quoted by producer Jerry Sherlock in Variety as the reason for the controversial casting of white star Peter Ustinov in Charlie Chan and the Curse of the Dragon Queen (Clive Donner 1981). ${ }^{33}$ Certainly issues of stardom have been argued as the reason for the casting of whites in the role of the Asian detective, but how does that then explain the casting of Asian American actors in the films Daughter of Shanghai, Phantom of Chinatown, and The Crimson Kimono? I argue it was not because Anna May Wong, Keye Luke, and James Shigeta had achieved a certain level of stardom. Shigeta was, for a period, the biggest Asian American star working in Hollywood and the only one groomed to play romantic leads; ${ }^{34}$ however, The Crimson Kimono was his film debut. Anna May Wong had attained a certain level of star status in the U.S. but mainly in B-level films, and Keye Luke was only known amongst Chan fans for having played Chan's “Number One Son.” Rather than a question of stardom, I argue it is because the detectives they played were not Asians (foreigners) but Asian Americans (citizens).

\section{“A Modern Copy”}

Daughter of Shanghai features not one but two Asian American actors, Anna May Wong and Philip Ahn, in the leading roles. ${ }^{35}$ Surprisingly, reviewers at the time did not regard the lack of a white lead as problematic. In fact, the reviewer for Variety suggests that the film's ties to current events could be used to attract audiences. He describes the film as "Stereotype crime meller, with the Shanghai label pasted on as a sop to current interest in the Sino-Jap fracas”36 and a Paramount studio memo confirms this ploy. ${ }^{37}$ The Paramount pressbook produced for exhibitors also stressed an exposé angle regarding the fact that thousands of Chinese aliens are smuggled into the States annually. The pressbook, however, also highlighted the "Americanness” of Ahn and Wong, notably that Ahn does not speak Chinese (although not mentioned is that he is, in fact, Korean American) and that Wong was born and went to high school in Los Angeles. Indeed, as the article pointed out, rather than use her Chinese name, Wong Liu Tsong, Wong went by an American name-Anna May. ${ }^{38}$

Daughter of Shanghai begins with respected Chinatown merchant, Quan Lin (Ching Wah Lee), murdered after he threatens to hand over evidence to government agents about a smuggling racket. His daughter Quan Lan Ying (Anna May Wong) investigates the criminal 
racket on her own and, following up on her father's lead, she travels to an island in the Caribbean, working undercover as a dancer at the nightclub through which aliens arrange passage on a ship bound for San Francisco. Here she joins efforts with Kim Lee (Philip Ahn), a Chinese American agent for the Department of Justice. Working together, the two of them discover that the head of the smuggling business is none other than a wealthy client of Lan Ying’s father, Mrs. Mary Hunt (Cecil Cunningham)—notably a white, American, woman.

Both Lee and Lan Ying are presented as assimilated into American society: Lee is a government agent living in Washington D.C. and Lan Ying makes a point to voice her status as an American. The film begins with Lan Ying modeling an antique Chinese ensemble for Mrs. Hunt at the Quan's Chinatown shop. She is so convincing as a "traditional” Chinese artifact that Mrs. Hunt asks, if the figure is "also antique"-assuming it is a mannequin. Coming to life, as it were, Lan Ying turns to face her and answers, “Only a modern copy.” Mrs. Hunt suggests that Lan Ying would “make a perfect princess” but the young woman replies, "I would rather be Lan Ying Quan, thank you"-in other words, a modern Chinese American woman rather than an antiquated ideal of Chinese femininity. Indeed, as the film progresses, Lan Ying's clothes become increasingly modern and Western. The film concludes with her acceptance of Lee's proposal of marriage meaning that she will leave behind her Chinatown community and father's business to live in mainstream D.C. society. Any threat that Lan Ying might represent to white men and/or audiences as an adventuress is contained as she is married off to an Asian American man. The film strictly adheres to Hollywood generic codes by seeing its independent woman returned to a more traditional and socially acceptable role but also its Production Code rules in denying the opportunity of interracial romance or miscegenation.

And yet there is something transgressive about the film in terms of the representation of race. Sean Metzger argues that, through the wearing of modern as opposed to traditional Chinese dress in her films, Anna May Wong “could fabricate a vision of China that was, at times, wholly consistent with the U.S. drive for capital gain and the racial inequities such a drive might entail, while simultaneously articulating a pattern of resistance to the hegemonic system that so often abused her." 39 While Asian detectives like Charlie Chan and Mr. Wong could embody a new modern kind of “Asianness” through Western dress (they typically sported Western suits and hats), they could not offer a subversion of the stereotypes they embodied (even if they could mock them) because the actors playing them were white in “yellowface;” however, Anna May 
Wong could because she was Chinese American. In addition, while completing their separate undercover investigations, Lee watches Lan Ying perform an exotic dance number and they exchange what Hye Seung Chung calls, the "gaze of recognition”: “The reciprocating, bilateral gaze mediates an ethnically codified ocular transaction that allows each to penetrate the 'veil of the other,' to see through the other's role-playing and masquerade." ${ }^{40}$ In other words, there is racial performance, but it is one knowingly enacted in order to dupe the ignorant white villains. Lastly, there are two key moments in Daughter of Shanghai in which the protagonists speak Cantonese but their exchanges are not translated for the mainstream audience. This suggests a recognition and brief privileging of a Chinese/American audience. The Chinese is not translated in the film (nor subtitled); however, the "Release Dialogue Script” (dated 8 Dec 1937) provides a translation of the final Chinese exchange in English, in parentheses.
Lee: [in English]
How would you like to live in Washington?
Lan Ying: [in English]
Perhaps the change of climate is just what I need.
Lee: [in English] Then it's settled.
Lan Ying: [in English]
Does that mean you're asking me to marry you?
Lee: [in Cantonese] What do you think?
Lan Ying: [in Cantonese] I am very happy you love me.

As incomprehensible to the film's assumed mainstream audience, the final two lines of dialogue could be argued to undermine the suggestion that Lee and Lan Ying are fully assimilated into American culture. Rather than belonging firmly to either/or, they are mediators between East and West, the traditional and the modern, Asia and America. However, this ending also contains any threat that Ahn and Wong may have posed as sexualized Asian Americans. As Chung argues, “Ahn placated the mainstream spectatorial anxiety about white-yellow miscegenation by containing Anna May Wong’s sexuality within same-race coupling.”41

Three years later, Keye Luke, who played Chan’s “Number One Son” in eight of the Oland-Chan films, took over the lead role as the amateur sleuth, Mr. Wong, for the last film in that series, Phantom of Chinatown, in a kind of prequel (although set in the present) to the Karloff films. Unlike Oland, Toler, Winters, Lorre, and Karloff_-Luke was Chinese American. The irony is that Luke's youthful detective is actually presented as less “Asian” (by Hollywood's stereotyped definition) than Karloff's adult version. Gone is the calm, reserved manner and slow, meditative way of speaking with an English accent of the Oxford-educated James Lee Wong. 
Instead Jimmy, much more like Chan’s “Number One Son” who was known to exclaim “Gee whiz, Pop!” on a regular basis, is an energetic, physically-active, outspoken American youth. As Karla Rae Fuller explains, the archetype of the "Oriental detective” is created through the interplay of several elements of performance, three significant ones of which are the "distinctive and distinguishable styles of speech" (namely the heavy accent, poetic speech, and reliance on “pidgin” English), the "formality in manner often expressed as politeness and courtesy toward the other main characters," and body language, "the most racially and culturally identifiable component of [which is] bowing." 42 Luke’s performances as Lee Chan and Jimmy Wong offer major departures from the archetype: his Asian American detectives are presented as fully acculturated rather than "othered.” Undoubtedly the appeal of Luke in the lead role (as opposed to another Asian/American actor), and the reason why Monogram felt comfortable having a nonwhite actor in the lead, is that Luke was already an established and well-liked actor from his role in the Chan films. In fact, following Oland's death in 1938, Luke was tested for a series tentatively titled Son of Chan but, according to film historian Jon Tuska, Fox executives thought that Oland was too closely associated with the detective to introduce another actor into the role (even though they would cast Toler less than a year later). ${ }^{43}$

Phantom of Chinatown follows the investigation of Jimmy Wong (Luke) into the death of the archaeologist Dr. Benton who, on a recent expedition to China, has discovered an ancient scroll with the secret of the Temple of Eternal Fire. The film offers two Chinese American characters, Jimmy and Benton's secretary Win Len (Long), at the centre of the narrative, and contains moments of racial awareness and attempts to debunk many white misconceptions about Chinese Americans. For example, police Captain Street (Grant Withers) asks out of ignorance if Win Len, eats chop suey every day for lunch (he is informed that she had coffee and apple pie), and if Jimmy and she know each other because they are both Chinese Americans. ${ }^{44}$ Jimmy’s intimacy with San Francisco’s Chinatown community affords Street the knowledge to uncover vital information in the case to which the police would otherwise not have access. Jimmy calls on the community's “revered elder” for information about a missing Chinese scroll and about Win Len, referring to her as a "daughter of the moon flower" and asking if "she is known to the friends of China.” For Captain Street, the seemingly poetic and coded language of the conversation might well have been Chinese for all that he understands and he retorts, "Look, I've got troubles enough without having to worry about figuring out Chinese proverbs.” Jimmy, thus, 
is presented as a mediator between East and West, living and working in white mainstream society but retaining his ties to his "other" culture. As Jimmy says, in regards to the missing scroll that both the Chinese and American governments want, "Naturally, my sympathies follow my heritage but, after all, I am an American.” Of note is the fact that Luke is not the only Asian American actor cast in a major role in this film: Lotus Long, who appeared in three previous Wong films and one Moto film in minor roles, is here promoted to Jimmy's investigative partner and love interest. By the end of the film, she is revealed to be an agent for the Chinese government working undercover in an attempt to retrieve the scroll. Notably, she is presented as neither a villainous "Dragon Lady” nor a submissive "Lotus Blossom” stereotype but as an intelligent and resourceful woman, entrusted with the future of China. The film is remarkable for being the only one to have an Asian American actor play one of the popular series detectives and attempt to expose American stereotypes of Asian American culture; however, it would seem that the film was not popular enough with audiences to see Luke continue in Karloff's place as this is the last film in the series. ${ }^{45}$ What the experiments Daughter of Shanghai and Phantom of Chinatown seem to prove-since they are the only attempts to cast Asian Americans as Hollywood detectives and Hollywood continued to employ white stars in "yellowface" for the rest of the Chan series throughout the 1940s — is that the Asian American detective was not as popular as the Asian detective. It is, thus, surprising that James Shigeta's debut was popular as Hollywood's second Japanese/American detective (Moto being the first) in The Crimson Kimono.

\section{Solving His Own "Case"}

The Crimson Kimono follows the investigation of a Japanese American police detective, Joe Kojaku (James Shigeta), and his Anglo American partner, war buddy, and roommate, Charlie Bancroft (Glenn Corbett). The film begins with the shooting of a stripper, Sugar Torch (Gloria Pall): the camera cuts from her collapse in the street to a close-up of Joe. At first the connection is unclear: is he her killer or her lover? However, the first words spoken in the film are his and confirm his authority as a detective. Joe asks, “Did she have a Japanese boyfriend?” because her dressing room is decorated with "Oriental artwork." The artwork was for a new act she was developing "to crack Vegas with” called "The Crimson Kimono," and includes pictures of a karate expert smashing bricks and another of Sugar in a kimono and black wig: the former leads 
Joe to the karate expert's friends at a karate club, and the latter leads his buddy Charlie to Chris (Victoria Shaw) — a young, attractive, art student. Joe is proven a more dedicated homicide detective than his partner because he cares about Sugar, perhaps because, like him, she is marginalized (although due to class not race) in the world of Los Angeles:

Joe: $\quad$ Listen, Charlie, I'm hanging on till we wrap it up....

Charlie: Joe, will you take it easy? Nobody cares who killed that tramp. Joe: $\quad$ Well, I do!

Charlie’s main focus becomes art student, Chris. Complicating the situation, however, is that Chris and Joe have fallen in love with each other and the triangle that forms then sets the two war buddies against one another. At the beginning of the film, Charlie is a sworn bachelor and Joe has been having trouble with his love life. He has been dating a Kibei (a Japanese American born in the U.S. but educated in Japan) whereas he is Nisei (second generation Japanese American), and he complains, "We never agree on anything. All we do is get into beefs about the old country.” And his problems with his love life are symptomatic of his bicultural identity as a Japanese American, especially since he has fallen in love with a white woman like Chris. Joe lives with a foot in both worlds, working in mainstream society but maintaining ties to the Japanese community, and it is these ties to L.A.'s Little Tokyo that give him the majority of the leads on Sugar's case. Interestingly, in the Little Tokyo sequences, the conversations in Japanese are not translated or subtitled, aligning mainstream viewers with Charlie rather than Joe, and establish Joe as a cultural mediator in the footsteps of Hollywood's earlier Chinese American detectives Quan Lan Ying, Kim Lee, and Jimmy Wong.

Race is raised as an issue but not necessarily racism. It is made explicit that Joe (and other Japanese Americans) fought for the U.S. in the Korean War despite the internment of Japanese Americans during World War II, suggesting that “all is forgiven” for the Japanese American community. As Peter X. Feng noted in his commentary when the film was screened on television's Turner Classic Movies channel in June 2008, The Crimson Kimono suggests that racism is not the reality of mainstream American society, but the paranoid fantasy of the one who is raced. In other words, if there is a problem, the problem lies not with the Anglo American, Charlie, but with the Japanese American, Joe. When Joe realizes he is in love with Chris, he chooses not to tell Charlie in order to avoid hurting him, but bottling up his feelings makes him behave distantly to his best friend. Charlie suspects that something has happened 
between Joe and Chris but he jumps to the wrong conclusion: he assumes that Chris has said something racist to Joe. Charlie explains to her, "Sometimes people drop a remark; a harmless one, you know.... Sometimes people forget... a word slips.” When Joe refuses to pursue his feelings for her, Chris assumes that race is also the reason; however, Charlie's older female friend, Mac (Anna Lee), explains that the problem is not race but Charlie. "What those two had together in the war, no one could touch,” Mac explains to Chris. Midway through the film, Charlie and Joe corner Sugar's presumed killer, Shuto (Fuji), the Korean karate expert who was helping her develop the new show. Each buddy takes turns striking Shuto when he resists arrest. As David Sanjek notes, Shuto’s beating is “not only indicative of the cooperative nature of their relationship as friends and investigative partners, but it also allows the anxiety that is building up in the two of them over Chris to have a convenient target.” ${ }^{46}$ Later, the two buddies are pitted against each other in a climactic fight scene at a kendo match (a Japanese martial art based on traditional swordsmanship); here Joe and Charlie finally vent their anger at each other. As Joe’s strikes against Charlie become increasingly violent, the spectators become concerned and one asks, “What's the matter with Kojaku?” Another exclaims, “He’s breaking all the rules!” While the spectator means that Joe is breaking the rules of kendo, Joe is also breaking the rules of society by falling in love with an Anglo American woman.

After the fight, Joe confesses to Charlie that the true reason for his sulky and subsequently explosive behavior is that he is in love with Chris. Charlie asks, "You mean you want to marry her?” The camera zooms in on Joe’s face and he says angrily, “You wouldn't have said it that way if I were white... Look at you! It's all over your face.” Charlie thinks that Joe has "gone crazy" but Joe storms out to pack up, quit the force, and leave L.A. It is left to Chris to reason with him and convince him to stay:

Joe: It wasn’t just plain, normal jealousy. That’s why those words poured out of me. When I saw his face, I knew.

Chris: You only see what you wanted to see.

Joe: $\quad$ You weren't there.

Chris: I know how he feels about those things.

Joe: I saw that look, Chris. It's a look I've never seen before on his face or anybody else's. I'm no wet nose! Nothing like that should have me below the belt.

Chris: He didn’t mean it that way. 
Joe: You don't have to mean it or say it...it's there all the time!

Chris: It's what you think is behind every word and every look.

Joe: You've got to wear my shoes to know what I'm talking about.

Chris: But I do know.

Joe: How could you know?... Honey, how could you? You can't feel for me unless you are me. Take a good look, Chris. Do I look different to you than I did yesterday?

Chris: Joe...

Joe: Did my face change?

Chris: Don't say that.

Joe: I've got to say it. I never felt this in the army, in the police. Maybe it's 5,000 years of blood behind me, busting to the front. For the first time I feel different. I taste it right through every bone inside me. For the first time, I catch myself trying to figure out who I am. I was born here; I'm American. I feel it and live it and love it, but down deep what am I? Japanese American, American Japanese, Nisei...? What label do I live under, Chris...You tell me.

Joe plans to leave town but it is at that precise moment that a break in the case occurs and Joe's detective instincts supplant his personal crisis. Suddenly, Joe and Charlie find themselves reunited in their pursuit of Sugar's killer—-revealed to be Roma (Jaclynne Greene), the woman who made Sugar's geisha-style wig. Joe and Charlie chase Roma through the streets filled with crowds celebrating "Nisei Week" in Little Tokyo. East and West come together both in terms of the crowds (composed of Japanese Americans and Anglo Americans) and in terms of the music (as traditional Japanese music alternates with the sounds of the Western brass band).

Joe shoots and Roma falls in the street just as Sugar, her victim, had done in the opening scene of the film. As she lies dying in Joe's arms, Roma confesses that she killed Sugar because she thought that the stripper was having an affair with Roma's lover but, in the end, realizes that it was "all in [her] mind.” Joe realizes that he too has been driven by his own fears, and the film suggests that the real problem is not that America is racist, but that Americans with hybrid identities struggle to find their place between their heritage and America's melting pot. As Sanjek suggests, "while [Joe] does not disdain his heritage, he craves assimilation as much as he loathes the potential for racial bigotry." ${ }^{47}$ At the end of the film, Charlie says to Joe, "I'm just as 
glad as you are that you finally wrapped up your own case"-in other words, the question of his identity. Joe had to sever his ties to his blood brother, Charlie (in Korea, Joe gave blood to save Charlie's life), in order to be ready for a mature and healthy relationship with a woman. And the kiss between Joe and Chris that concludes the film is a landmark kiss: the first on the big screen between an Asian/American man and a white woman. As Gina Marchetti suggests, however, the power of that kiss is tempered by the denial of racism that precedes it:

The Crimson Kimono's denial of racism must perplex some viewers as much as the interracial kiss would provoke others.... The Crimson Kimono really cannot be taken seriously as the daring antiracist statement promised by that kiss, since it also so vehemently demands that the racism it combats is all an illusion. ${ }^{48}$

\section{American Action Heroes}

While Daughter of Shanghai, Phantom of Chinatown, and The Crimson Kimono explore the specificity of marginal experience in mainstream culture and bring it to the centre of the narrative, ultimately they offer a similar message as Hollywood's “yellowfaced” Asian detective films: namely, that "otherness" is desirable only when assimilated into mainstream culture. In Hollywood's mind, assimilation meant acceptance of the "other” into the mainstream and was regarded as a positive thing. Although regarded today as merely token representations, the Asian detectives were considered, at the time, as an antidote to the racist stereotypes that had preceded them. Jon Breen argues, “to call him a stereotype falsifies history.... In fact, Chan was conceived as an anti-stereotype, but even that label is unfortunate, since it diminishes his stature as a complex, individual, and fully-developed character." ${ }^{49}$ Whether or not Asian American studies scholars would agree with Breen's assertion in regards to Chan they would more likely agree that the detectives played by Wong, Ahn, Luke, and Shigeta are complex, individual, and fullydeveloped characters.

Importantly, it was most often in secondary or primary singular (rather than serial) roles that Asian American characters were played by Asian American actors and firmly aligned with ideals of American heroism: for example, Charlie Chan’s sons played by Edwin Luke (in one film), Benson Fong (in seven), Keye Luke (in ten), and Victor Sen Yeung (in eighteen). ${ }^{50}$ Lee Chan (Keye Luke), may be young and inexperienced when compared to his father, but it is he who is allowed to be the man of action and romance and is thus aligned with American ideals of 
heroism. While his father's engagement in violence tended to be reduced to the drawing of a gun and rarely firing it, Lee literally leaps into action. In Charlie Chan in Shanghai (James Tinling 1935), for example, Lee kicks the gun out of one villain's hand, smashes a chair over another, and jumps from the top of a flight of stairs onto a third in order to rescue his father from his kidnappers. Also unlike his father, Lee is sexualized: he flirts with young Chinese/American women and plans dates with them (even if those dates usually get cancelled because of the case at hand). Similarly, although Mr. Wong as embodied by Karloff was denied sexuality, Jimmy as portrayed by Luke enjoys a budding romance with Long’s Win Len.

Tied to their roles as cultural mediators, Kim Lee, Jimmy Wong, and Joe Kojaku prove to be-like Chan — cerebral sleuths (i.e., using their intelligence to outwit the villains) butunlike Chan—also physical fighters of crime (i.e., using bodily skills to combat the enemy). For example, in Daughter of Shanghai, Lee is given the opportunity to act heroically and save Lan Ying at the end of the film. At the beginning of the film, two of the smugglers are flying a small cargo of illegal aliens into San Francisco when they spot a government plane tailing them. Rather than be caught in the act, they choose to dump their "cargo," opening the cargo hatch and allowing their six passengers to fall to their deaths in the ocean below. Similarly, when Lan Ying and Lee are discovered working undercover, the smugglers decide to dispose of the problem in the same manner. Rather than sit passively, transfixed by terror, and doing nothing —as did the original group of illegal aliens_-Lee takes action: he evaluates the layout of the cargo hold and then instructs Lan Ying to brace herself in a specific spot. When the villains open the cargo hold, Lee grasps on to the inside of the plane and then holds both their weights when Lan Ying loses her grip and is forced to cling onto him. After the plane lands on the water and the villains leave, Lee then punches their way out of the hold into the cockpit and disables the plane to prevent the villains' getaway before helping Lan Ying swim to shore.

Similarly, in Phantom of Chinatown, Jimmy proves to be as much a man of action as he is a skilled sleuth. Certainly, while Captain Street and another police officer literally sit doing nothing, Jimmy puts his hunch to the test and searches the university grounds at night for the glass with which Dr. Benton was poisoned. And, unlike his Chinese/American predecessors (including Daughter of Shanghai's Kim Lee), Jimmy carries a gun and, more significantly, uses it. He shoots open the door to the hideout but saves his bullets when the villains, fleeing in a boat, are too far away to strike, unlike the impatient Captain Street who fires off several rounds 
into the distance. Jimmy then lays a trap to draw out Benton's killer: announcing in the papers and over the radio that Mason (John Holland), the missing pilot of the Benton expedition, has been found, Jimmy then poses as Mason in the hospital. It is only a matter of time before the killer makes an attempt on Mason/Jimmy’s life but Jimmy has laid a double trap: not only does Fraser (John H. Dilson), Benton's cameraman, show up to kill Mason but Mason also comes out of hiding to kill Fraser, his partner-in-crime who double-crossed him and left him for dead in the desert. A struggle ensues and Jimmy fights valiantly with Mason, landing several punches, directing Mason's gunshots harmlessly into the air, and then pinning him to the ground until Street and his men arrive to apprehend the criminals. Even though Jimmy may have investigated alongside Street for the majority of the film, the final and physical victory is his.

In The Crimson Kimono, although Joe spends much of the film completing leg work (literally pounding the pavement following up leads), he is ultimately also a man of action. When Joe first confronts Shuto, the karate expert lifts Joe over his head and tosses him into a pile of trash. Shuto may have surprised Joe with his strength initially, but Joe is better prepared for their second meeting in the pool hall: this time he calls Charlie for backup. Although, on the phone, Charlie tells Joe not “to do anything foolish,” Joe has already started a confrontation with Shuto by the time Charlie arrives. In an interesting series of alternating shots, Charlie takes punches and Joe karate strikes until, between them, they subdue Shuto. In many ways, Joe's problems begin when he forces himself not to act, and not in terms of the investigation but in terms of his personal feelings for Chris. As Joe explains to Charlie after their violent kendo match, “On account of you, I never even touched her. I wanted to hold her in my arms, but I couldn't. I didn’t want to hit you that way, Charlie, but it’s not normal to keep my feelings bottled up.” At the same time, he encourages Charlie to take action: "Say something. Blow your top! Belt me! You've got the right to belt me!” Joe’s crisis is resolved when he can once again take actionthis time, wrapping up the mystery of Sugar's murder. Charlie and Chris find Joe in a diner on his way out of town and try to talk him into staying, but Chris spies Hansel (Neyle Morrow), the librarian who was helping Sugar with her new act, and the two detectives give chase. They corner him and demand to know why he shot Sugar; however, Roma, his lover, appears and takes a shot at Charlie before disappearing into the "Nisei Week" celebrations. Even though both heroes (Anglo American and Japanese American) are men of action, the camera focuses on Joe’s pursuit through the crowded streets, intercutting between shots of Roma running scared and Joe’s 
determined face. Roma spins and fires at Joe, missing, but he takes careful aim and shoots her squarely in the back. He is rewarded for his successful detective work with Roma's dying confession, and the realization it affords him regarding his own relationship with Charlie and his future with Chris, sealed with a kiss. Despite his assimilation into mainstream society, Joe Kojaku - as a Japanese American detective who is allowed to maintain ties to his community, pursue his sexual desires openly, and take action against crime-is markedly different from Hollywood’s isolated, asexual, “armchair,” Asian detectives like Chan, Wong, and Moto.

\section{Complexity of Representation}

In his book Charlie Chan: The Untold Story of the Honorable Detective and his Rendezvous with American History (2010), Yunte Huang suggests that “[t]he stories of Earl Biggers, Warner Oland, Sidney Toler, and Anna May Wong, among others, were all part of the cultural mélange that Gertrude Stein called 'The Making of Americans." "51 While I would agree that the various incarnations and aspects of the Asian detective have each had an impact on American popular culture, the aim of this paper has been to demonstrate that those of the Asian American detective represent a different kind of policing of the boundaries between Asian and American-including those embodied by Anna May Wong. What these representations of Asian American detectives suggest is that it is not the race of the actor that was regarded as potentially problematic by Classical Hollywood producers but rather the race of the main character. Importantly, Charlie Chan is Asian-not Asian American. The concern about race for Classical-era film producers was less race and more cultural or national difference: the Asian American detective is regarded as less "other" and less threatening to the American way of life than the foreign-born Asian detective played by white actors. The assimilated Asian American detectives of Classical Hollywood may, by today’s standards, be regarded as more token rather than critical explorations of marginalized subjectivity and mainstream racism; however, at the time and according to Hollywood, these assimilated heroes were regarded as positive characters and afforded them a complexity of representation not permitted for their far more famous and prolific “yellowface” counterparts. 


\section{Acknowledgements}

The author gratefully acknowledges that financial support for this research was received from a grant funded partly by Wilfrid Laurier University Operating funds and partly by the SSHRC Institutional Grant awarded to Wilfrid Laurier University. 


\section{NOTES}

${ }^{1}$ In this paper, I use the term “Asian” because Charlie Chan and Mr. Wong are Chinese but Mr. Moto and Joe Kojaku are Japanese.

2 See Yunte Huang, Charlie Chan: The Untold Story of the Honorable Detective and his Rendezvous with American History (New York: W.W. Norton \& Co., 2010) for more on Chan's critical reception (especially Ch. 29).

${ }^{3}$ Hye Seung Chung, Hollywood Asian: Philip Ahn and the Politics of Cross-Ethnic Performance (Philadelphia: Temple University Press, 2006), 10.

${ }^{4}$ Sue Fawn Chung, "From Fu Manchu, Evil Genius, to James Lee Wong, Popular Hero: A Study of the Chinese-American in Popular Periodical Fiction from 1920 to 1940,” Journal of Popular Culture 10.3 (1976): 535.

${ }^{5}$ Doobo Shim, "From Yellow Peril through Model Minority to Renewed Yellow Peril,” Journal of Communication Inquiry 22.4 (1998): 388.

${ }^{6}$ Krystyn R. Moon, Yellowface: Creating the Chinese in American Popular Music and Performance, 1850s-1920s (New Brunswick, NJ: Rutgers University Press, 2005), 56.

${ }^{7}$ Eugene Franklin Wong, "The Early Years: Asians in the American Films Prior to World War II,” in Screening Asian Americans, ed. Peter X. Feng (New Brunswick, NJ: Rutgers UP, 2002), 58.

${ }^{8}$ Sax Rohmer (1916), The Return of Dr. Fu Manchu (New York: Pyramid Books, 1965), 7.

${ }^{9}$ See Sue Fawn Chung, 534-47.

${ }^{10}$ Charles J. Rzepka, “Race, Region, Rule: Genre and the Case of Charlie Chan.” PMLA 122.5 (2007): 1463-81.

11 Oscar Rimoldi, “The Detective Movies of the 30s and 40s: Part I," Films in Review 44.5/6 (1993): 170.

12 George Kuwa in House without a Key (1925), Kamiyama Sojin in The Chinese Parrot (1927), and E. L. Park in Behind that Curtain (1929).

13 Charlie Chan Carries On (1931), The Black Camel (1931), Charlie Chan's Chance (1932), Charlie Chan's Greatest Case (1933), Charlie Chan's Courage (1934), Charlie Chan in London (1934), Charlie Chan in Paris (1935), Charlie Chan in Egypt (1935), Charlie Chan in 
Shanghai (1935), Charlie Chan's Secret (1936), Charlie Chan at the Circus (1936), Charlie Chan at the Race Track (1936), Charlie Chan at the Opera (1936), Charlie Chan at the Olympics (1937), Charlie Chan on Broadway (1937), and Charlie Chan at Monte Carlo (1937).

${ }^{14}$ Charlie Chan in Honolulu (1938), Charlie Chan in Reno (1939), Charlie Chan at Treasure Island (1939), City in Darkness (1939), Charlie Chan in Panama (1940), Charlie Chan's Murder Cruise (1940), Charlie Chan at the Wax Museum (1940), Murder Over New York (1940), Dead Men Tell (1941), Charlie Chan in Rio (1941), Castle in the Desert (1942), Charlie Chan in the Secret Service (1944), The Chinese Cat (1944), Black Magic (1944), The Jade Mask (1945), The Scarlet Clue (1945), The Shanghai Cobra (1945), The Red Dragon (1945), Dark Alibi (1946), Shadows Over Chinatown (1946), Dangerous Money (1946), and The Trap (1947).

${ }^{15}$ The Chinese Ring (1947), Docks of New Orleans (1948), The Shanghai Chest (1948), The Golden Eye (1948), The Feathered Serpent (1948), and The Sky Dragon (1949).

${ }^{16}$ Mr. Wong, Detective (1938), The Mystery of Mr. Wong (1939), Mr. Wong in Chinatown (1939), Doomed to Die (1940), The Fatal Hour (1940), and Phantom of Chinatown (1940).

${ }^{17}$ Think Fast, Mr. Moto (1937), Thank You, Mr. Moto (1937), Mr. Moto's Gamble (1938), Mr. Moto Takes a Chance (1938), Mysterious Mr. Moto (1938), Mr. Moto's Last Warning (1939), Mr. Moto in Danger Island (1939), and Mr. Moto Takes a Vacation (1939).

${ }^{18}$ In the "Second Outline" for Charlie Chan at the Opera (dated 11 Jul 1936) the writers Scott Darling and Charles S. Belden leave sections of dialogue unwritten; in its place they leave only "Chan speaks in proverbs" or "offers a typical Chanism.” All the scripts, treatments, and outlines referred to in this paper were reviewed at the USC Cinema and Television Library.

${ }^{19}$ Rimoldi, 170.

${ }^{20}$ Jun Xing, Asian American through the Lens: History Representations, and Identity (Walnut Creek, CA: AltaMira Press, 1998), 61.

${ }^{21}$ See Yuko Kawai, "Stereotyping Asian Americans: The Dialectic of the Model Minority and the Yellow Peril,” The Howard Journal of Communications 16 (2005): 109-30.

${ }^{22}$ Karla Rae Fuller, Hollywood Goes Oriental: CaucAsian Performance in American Film (Detroit: Wayne State University Press, 2010), 73. 
${ }^{23}$ Ed Guerrero, “The Black Image in Protective Custody: Hollywood’s Biracial Buddy Films of the Eighties," in Black American Cinema, ed. Manthia Diawara (New York: Routledge, 1993), 237. Guerrero is using the term "strategies of containment" as defined by Frederic Jameson, The Political Unconscious: Narrative as a Socially Symbolic Act (Ithaca, NY: Cornell UP, 1981).

${ }^{24}$ Lisa Lowe, Immigrant Acts: On Asian American Cultural Politics (Durham, NC: Duke UP, 1996), 11-12.

${ }^{25}$ David L. Eng, “Introduction: Racial Castration,” in Racial Castration: Managing Masculinity in Asian America, ed. David L. Eng (Durham, NC: Duke UP, 2001), 1.

${ }^{26}$ Shim, 390.

${ }^{27}$ In light of the vilification of the Japanese in Hollywood, Mr. Moto was presented differently from Chan and Wong. Lorre portrays Moto as a quiet, seemingly meek, detective who drinks milk when others have scotch; however, beneath a veneer of Asian politeness and small stature (Lorre was 5'5”) is a calculating, intelligent, and sometimes menacing man-unlike Chan and Wong. What differentiates Moto from the Chinese model minority detectives is his proclivity for violence. He is an expert in the martial art of ju-jitsu and, with the help of a stunt double, Lorre as Moto engages in many exciting fights. While presenting Moto as a physical fighter of crime could align him with more American notions of heroism, Moto knocks his enemies about like a whirling dervish. In these films, his martial arts skills are presented as exotic and "other" in comparison to more typical American demonstration of might—for example, fist fights.

${ }^{28}$ Gina Macdonald and Andrew Macdonald, "Ethnic Detectives in Popular Fiction: New Directions for an American Genre,” in Diversity and Detective Fiction, ed. Kathleen Gregory Klein (Bowling Green, OH: Bowling Green State U Popular P, 1999), 60.

${ }^{29}$ Andrew Wallenstein, “Discussions added to Chan fest," Hollywood Reporter, Sept 2, 2003, 3.

${ }^{30}$ Herman Wong, “Charlie Chan: Denying the White Man in Yellow Face,” Los Angeles Times, Oct 22, 1983, 4; emphasis in the original.

${ }^{31}$ Qtd. in Ken Hanke, Charlie Chan at the Movies: History, Filmography, and Criticism (Jefferson, NC: McFarland \& Co., 1989), xv.

${ }^{32}$ Qtd. in Ken Hanke, xv. 
${ }^{33}$ Qtd. in Richard Goldstein, “The Chan Syndrome,” Village Voice, May 5, 1980.

${ }^{34}$ Henry Ong, "James Shigeta: Leading Man Emeritus," Goldsea: Asia American Daily, http://goldsea.com/Personalities2/Shigetaj/shigetaj.html (accessed Apr 11, 2010), ף2.

${ }^{35}$ Anna May Wong also plays a quasi-detective in the Warner Bros. film When Were You Born (1938) as an astrologer who helps solve a murder and uncover a drug-smuggling operation.

${ }^{36}$ Hobe., Review of Daughter of Shanghai, Variety, 29 Dec 1937, 17.

${ }^{37}$ Harold Hurley, Memo to A. M. Botsford, Paramount, 14 Jul 1937. Viewed at the Margaret Herrick Library (April 2008).

${ }^{38}$ The Paramount pressbook and production file for Daughter of Shanghai were viewed at the Margaret Herrick Library (April 2008).

${ }^{39}$ Sean Metzger, "Patterns of Resistance?: Anna May Wong and the Fabrication of China in American Cinema of the Late 30s," Quarterly Review of Film and Video 23.1 (2006): 11.

${ }^{40}$ Hye Seung Chung, 81.

${ }^{41}$ Hye Seung Chung, 73.

${ }^{42}$ Fuller, 84 and 91.

${ }^{43}$ Jon Tuska, In Manors and Alleys: A Casebook on the American Detective Film (Westport, CT: Greenwood Press, 1988), 176.

${ }^{44}$ Notably, Lotus Long was not actually Chinese American; she is of Hawaiian and Japanese descent.

${ }^{45}$ I argue that this is less necessarily to do with the casting of an Asian American actor in the lead role and more to do with the mediocre quality of the film in general. Poor scripting, somewhat wooden acting, and uninspiring cinematography and editing make this film often slow and uninteresting to watch.

${ }^{46}$ David Sanjek, “'Torment Street between Malicious and Crude:' Sophisticated Primitivism in the Films of Samuel Fuller,” Literature/Film Quarterly 22.3 (1994): 190.

${ }^{47}$ Sanjek, 190.

${ }^{48}$ Gina Marchetti, Romance and the "Yellow Peril:" Race, Sex, and Discursive Strategies in Hollywood Fiction (Berkeley: University of California Press, 1993), 157.

${ }^{49}$ Jon L. Breen, “Charlie Chan: The Case of the Reviled Detective,” Mystery Scene 82 (2003): 27. 
${ }^{50}$ Philip Ahn was Korean American, born in Los Angeles. As well as starring in Daughter of Shanghai (1937) as Kim Lee, Ahn played Wing Foo, Chan's Son-in-Law, in Charlie Chan in Honolulu (1938), Prince Chung in Thank You, Mr. Moto (1937), and an uncredited role as a switchboard operator in Think Fast, Mr. Moto (1937).

Benson Fong was Chinese American, born in Sacramento. He played Tommy Chan ("Number Three Son”) in Dark Alibi (1946), Red Dragon (1945), The Shanghai Cobra (1945), The Scarlet Clue (1945), Charlie Chan in The Chinese Cat (1944), and Charlie Chan in the Secret Service (1944). He also played an uncredited "opera extra" in Charlie Chan at the Opera (1936).

Lotus Long (aka Karen Sorrell) came to California in 1920. Her father was of Japanese background and her mother Hawaiian but Long was generally assumed to be Chinese. As well as starring in Phantom of Chinatown (1940), Long also played Princess Lin Hwa (the murder victim) in Mr. Wong in Chinatown (1939), and minor roles in The Mystery of Mr. Wong (1939), Mysterious Mr. Moto (1938), and Think Fast, Mr. Moto (1937).

Keye Luke was born in Guangzhou, China, and raised in Seattle, Washington. He played Lee Chan ("Number One Son") in Charlie Chan in Paris (1935), Charlie Chan in Shanghai (1935), Charlie Chan at the Circus (1936), Charlie Chan at the Race Track (1936), Charlie Chan at the Opera (1936), Charlie Chan at the Olympics (1937), Charlie Chan on Broadway (1937), Charlie Chan at Monte Carlo (1937), The Feathered Serpent (1948), The Sky Dragon (1949), and in Mr. Moto's Gamble (1938).

Victor Sen Yung (aka Sen Yung, Sen Young, Victor Young) was Chinese American, born in San Francisco. He played Jimmy Chan ("Number Two Son”) in Charlie Chan in Honolulu (1938), Charlie Chan in Reno (1939), Charlie Chan at Treasure Island (1939), Charlie Chan in Panama (1940), Charlie Chan's Murder Cruise (1940), Charlie Chan's Murder Cruise (1940), Charlie Chan at the Wax Museum (1940), Murder Over New York (1940), Dead Men Tell (1941), Charlie Chan in Rio (1941), Castle in the Desert (1942), Shadows Over Chinatown (1946), Dangerous Money (1946), and The Trap (1946)—as well as Chan's "Number Three Son," Tommy, in The Chinese Ring (1947), Docks of New Orleans (1948), The Shanghai Chest (1948), The Golden Eye (1948), and The Feathered Serpent (1948). 
Lastly, he played uncredited roles as an onlooker in the scene with the street acrobats in Thank You, Mr. Moto (1937), and as a Khmer soldier in Mr. Moto Takes a Chance (1938).

${ }^{51}$ Huang, 296. 